\title{
Pengukuran Respon Kelelahan Menggunakan FACIT Score Pada Pasien Jantung Yang Mendapatkan Perawatan Di Ruang Intensif
}

\author{
Wahyuni, N., S. ${ }^{1}$, Damanik, C. ${ }^{2}$, Sholichin ${ }^{3}$ \\ ${ }^{1}$ Mahasiswa Program Studi Ilmu Keperawatan ITKES Wiyata Husada Samarinda, J1. Kadrie \\ Oening No.77, Samarinda, Kalimantan Timur. \\ e-mail: nursriwahyuni901@student.stikeswhs.ac.id \\ ${ }^{2}$ Dosen Program Studi Ilmu Keperawatan ITKES Wiyata Husada Samarinda, Jl. Kadrie Oening \\ No.77, Samarinda, Kalimantan Timur. e-mail: chrisyendamanik@stikeswhs.ac.id \\ ${ }^{3}$ Dosen Program Studi Keperawatan Akademi Keperawatan Pemprov Kaltim, Jl. Anggur No.88, \\ Samarinda, Kalimantan Timur. e-mail: sholichin307@gmail.com
}

\begin{abstract}
Abstrak
Latar belakang: Terganggunya fungsi jantung menyebabkan nutrisi dan oksigen yang dipompa ke sel di seluruh tubuh menjadi berkurang. Akibatnya, produksi energi berkurang dan menimbulkan respon kelelahan secara subyektif berupa rasa tidak berdaya baik fisik maupun psikologis pada pasien jantung. Tujuan: Mengetahui hasil pengukuran respon kelelahan menggunakan FACIT score pada pasien jantung yang mendapatkan perawatan di ruang intensif. Metode: Penelitian kuantitatif dengan rancangan studi deskriptif dan pendekatan cross sectional, dilaksanakan di ruang intensif di salah satu rumah sakit Kecamatan Tenggarong, yang melibatkan 12 pasien dengan teknik total sampling yang telah memenuhi kriteria inklusi yaitu pasien jantung yang mendapatkan perawatan intensif, dengan penyakit penyerta, menggunakan nasal kanul dan simple mask, dan berusia $\geq 15$ tahun. Pengumpulan data menggunakan kuesioner FACIT Score yang telah tervalidasi, dan analisis data dengan statistik deskriptif. Hasil: Skor kelelahan pada pasien berada pada median 21,00 dengan rentang skor 0-30. Sebagian besar pasien berada dalam kategori lelah. Kesimpulan: Sebagian besar pasien jantung yang mendapatkan perawatan di ruang intensif berada dalam rentang lelah. Rekomendasi: Diharapkan dapat digunakan sebagai acuan penelitian lebih lanjut terkait faktor-faktor yang mempengaruhi kelelahan pada pasien jantung, maupun dalam penelitian eksperimen mengenai manajemen kelelahan pada pasien jantung.
\end{abstract}

Kata kunci: kelelahan, pasien jantung, FACIT score 


\section{PENDAHULUAN}

Kelelahan merupakan kondisi fisiologis dimana seseorang mengalami kelemahan (atau keletihan) dari aktivitas yang berulang atau berkurangnya respons sel, jaringan, atau organ setelah stimulasi atau aktivitas yang berlebihan. Pada penyakit kardiovaskular, kelelahan menjadi salah satu manifestasi dimana pasien merasakan ketidakberdayaan secara fisik maupun psikologis akibat dari penurunan curah jantung, penurunan tekanan darah yang berimplikasi pada penurunan sirkulasi (Hirshkowitz, 2013; Nugraha \& Gusgus, 2018).

Sebanyak 55\% pasien dengan Infark Miokard mengalami kelelahan diatas ratarata. Sejumlah $50-98 \%$ pasien gagal jantung melaporkan kelelahan sebagai gejala yang paling umum terjadi pada pasien. Kelelahan memberikan kontribusi sebesar $28,3 \%$ terhadap risiko hipertensi pada anggota polisi. Sebanyak $45 \%$ pasien penyakit jantung koroner mengalami tingkat kelelahan yang berat. Kematian "dini" yang disebabkan oleh penyakit jantung terjadi berkisar sebesar $4 \%$ di negara berpenghasilan tinggi sampai dengan $42 \%$ terjadi di negara berpenghasilan rendah. Umumnya perempuan lebih rentan mengalami penyakit kardiovaskuler dibanding lakilaki karena faktor risiko seperti tingginya kadar LDL serta kurangnya aktifitas fisik (Martiningsih \& Haris, 2019; Putri, 2018;

Putri dkk, 2018; Rosjidi \& Isro'in, 2014; Wahyudi dkk, 2018; Zulaihah, 2019).

Pasien penyakit jantung umumnya mengalami ketidakseimbangan suplai darah dan oksigen akibat sumbatan plak pada arteri koroner serta iskemia jaringan.
Penurunan kadar oksigen pada pasien menyebabkan penurunan sediaan energi dalam tubuh dikarenakan proses penghasilan ATP juga berkurang, tubuh merespon dengan melakukan metabolisme anaerob yang menghasilkan zat sisa berupa asam laktat. Penumpukan asam laktat pada otot yang berlebih akan menyebabkan gelaja mudah lelah dan sesak nafas. Pada takiaritmia dapat menyebabkan jantung berdetak lebih dari 100 kali per menitnya. Kondisi ini mengakibatkan jantung mengalami kelelahan dan menimbulkan gejala berdebar-debar yang biasanya disertai perasaan takut karena debaran jantung yang begitu cepat. Kecemasan juga merupakan prediktor kelelahan secara psikologis sekaligus faktor komorbid kelelahan. Semakin tinggi skor kecemasan pasien maka semakin tinggi skor kelelahannya. Semakin tinggi umur pasien maka semakin tinggi pula kecenderungan pasien untuk menjadi lebih cemas sehingga pasien akan cenderung mengalami kelelahan (Anastasya dkk, 2016; Nugraha \& Gusgus, 2018; Nugraha dkk, 2018; Wahyudi dkk, 2018).

Kelelahan berdampak pada kurangnya kemampuan pasien untuk berfungsi dan melakukan kegiatan sehari-hari, adanya perasaan gagal, serta hilangnya motivasi berakibat pada kecenderungan untuk berhenti kerja, dan menurunnya produktivitas kerja. Pasien dengan gagal jantung menunjukkan $60 \%$ partisipan mandiri pada aktivitas sehari-harinya dan $40 \%$ dengan bantuan pada aktivitas sehariharinya (Matura dkk, 2018; Putri, 2018; Putri dkk, 2018; Sekarsari \& Ade, 2016; Wahyudi dkk, 2018). 
Myra Levine mengemukakan teorinya tentang konservasi energi dimana konservasi ini mampu memotivasi dan mendorong pasien mengeksplor dan memaksimalkan kekuatan dan energi pasien dalam mengatasi masalah secara fisiologis dan psikologis sehingga dapat meningkatkan proses penyembuhan pasien dan untuk mempertahankan kesehatannya. Teori ini mengajarkan pasien untuk dapat melakukan pelestarian energi terutama dalam mengurangi kelelahan pada pasien (Widiastuti, 2012).

Penelitian ini bertujuan untuk Untuk mengetahui hasil pengukuran respon kelelahan menggunakan FACIT score pada pasien jantung yang mendapatkan perawatan di ruang intensif.

\section{METODE}

Penelitian ini merupakaan rancangan penelitian deskriptif menggunakan pendekatan cross sectional dengan metode survey. Populasi pada penelitian ini adalah seluruh pasien dengan penyakit jantung yang ada di ruang ICU/ICCU dan HCU RSUD Aji Muhammad Parikesit Tenggarong dalam bulan Juni-Juli berjumlah 12 pasien. Sampel dalam penelitian ini adalah pasien dengan penyakit jantung yang ada di ruang ICU/ICCU dan HCU RSUD Aji Muhammad Parikesit Tenggarong. Penelitian ini menggunakan teknik sampling yaitu teknik Non-Probability Sampling dengan Sampel Jenuh atau Total Sampling. Kriteri inklusi penelitian ini adalah pasien jantung yang mendapatkan perawatan intensif, pasien jantung dengan penyakit penyerta, pasien dengan alat bantu pernapasan nasal kanul dan simple mask, serta pasien berusia $\geq 15$ tahun. Sedangkan kriteria ekslusi dalam penelitian ini adalah pasien dengan penurunan kesadaran dan pasien dengan kondisi kritis yang tidak memungkinkan untuk dilakukan penelitian.

Instrument yang digunakan berupa lembar karakteristik responden dan alat ukur FACIT score untuk mengukur kelelahan pasien, yang terdiri dari dari 13 item pertanyaan dengan pengukuran Skala Likert empat poin yaitu: (4) tidak sama sekali, (3) sedikit, (2) dalam jumlah sedang, (1) seringkali dan (0) sangat sering. Jumlah skor pada seluruh pertanyaan adalah 52. Jumlah skor kurang dari 30 menunjukkan kelelahan. Semakin tinggi skor maka semakin tinggi kualitas hidup pasien.

\section{HASIL ANALISIS UNIVARIAT}

\section{Karakteristik Responden} Karakteristik responden merupakan sesuatu yang melekat pada pasien, pada tabel dibawah ini dijabarkan karakteristik responden.

Berdasarkan Tabel 4.1 diketahui bahwa jenis kelamin laki-laki sebanyak 6 orang $(50 \%)$ setara dengan jumlah responden perempuan sebanyak 6 orang $(50 \%)$. Kemudian jumlah responden terbanyak berusia 66 tahun keatas (masa manula) sebanyak 4 orang $(33,3 \%)$. Pendidikan terakhir responden terbanyak adalah SD yaitu 5 orang $(41,7 \%)$ dan SMP yaitu 5 orang $(41,7 \%)$. Pekerjaan responden terbanyak adalah wiraswasta yaitu sebagai petani sebanyak 5 orang $(41,7 \%)$ dan tidak bekerja sebanyak 5 orang $(41,7 \%)$. Penghasilan responden terbanyak berada di bawah UMP Kaltim yaitu sebanyak 9 orang (75\%). Kemudian diagnosis terbanyak adalah NSTEMI sebanyak 5 orang $(41,7 \%)$. 
Tabel 4.1 Distribusi Frekuensi Berdasarkan Karakteristik Responden Dengan Penyakit Jantung Di Ruang Intensif RSUD Aji Muhammad Parikesit, Juni-Juli 2020

\begin{tabular}{ccc} 
& $(\mathrm{n}=12)$ & \\
\hline Karakteristik & Frekuensi & Persentase (\%) \\
\hline Jenis kelamin Laki-laki & & \\
Perempuan & 6 & 50 \\
& 6 & 50 \\
\hline
\end{tabular}

\begin{tabular}{lll}
\hline Usia & & \\
Masa dewasa awal (26-35 tahun) & 1 & 8,3 \\
Masa dewasa akhir (36-45 tahun) & 2 & 16,7 \\
Masa lansia awal (46-55 tahun) & 2 & 16,725 \\
Masa lansia akhir (56-65 tahun) & 3 & 33,3 \\
Masa manula (66 tahun keatas) & 4 & \\
\hline
\end{tabular}

\section{Pendidikan terakhir}

\begin{tabular}{lll} 
Pendidikan terakhir & & \\
SD & 5 & 41,7 \\
SMP & 5 & 41,7 \\
Sarjana & 2 & 16,7 \\
\hline Pekerjaan & & \\
$\quad$ Wiraswasta & 5 & 41,7 \\
$\quad$ Pensiunan & 2 & 16,7 \\
$\quad$ Tidak Bekerja & 5 & 41,7 \\
\hline Tingkat penghasilan Dibawah & & \\
$\quad$ UMP Kaltim & 9 & 75 \\
$\quad$ Diatas UMP Kaltim & 3 & 25 \\
\hline
\end{tabular}

Diagnosis penyakit

$\begin{array}{lcc}\text { AF Rafid } & 2 & 16,7 \\ \text { AMI } & 1 & 8,3 \\ \text { CHF } & 1 & 8,3 \\ \text { Hipotensi } & 1 & 8,3 \\ \text { NSTEMI } & 5 & 41,7 \\ \text { STEMI } & 2 & 16,7\end{array}$

\section{Respon Kelelahan}

Tabel 4.2 Tingkat Respon Kelelahan Menggunakan FACIT Score Pada Responden dengan Penyakit Jantung Di Ruang Intensif RSUD Aji Muhammad Parikesit, Juli 2020 ( $\mathrm{n}=12)$

\begin{tabular}{lcc}
\hline \multicolumn{1}{c}{ Indikator } & f & $\mathbf{\%}$ \\
\hline Lelah (skor $<30)$ & 7 & 58,3 \\
\hline Tidak Lelah (skor $>$ & 5 & 41,7 \\
30) & & \\
\hline \multicolumn{1}{c}{ Total } & 10 & 100 \\
\hline
\end{tabular}

Berdasarkan Tabel 4.2 dari hasil pengukuran kelelahan pada pasien jantung di ruang intensif dengan FACIT score diketahui bahwa sebanyak 7 responden $(58,3 \%)$ mengalami kelelahan kelelahan.
Sedangkan sebanyak 5 responden $(41,7 \%)$ tidak mengalami kelelahan.

\section{PEMBAHASAN 1. Karakteristik \\ Responden}

a. Jenis Kelamin

Hasil penelitian yang telah dilakukan mengenai jenis kelamin responden dengan penyakit jantung yang mendapatkan perawatan diruang intensif didapatkan jumlah responden perempuan dengan persentase sebanyak 50\% setara dengan jumlah responden laki-laki sebanyak 50\%. Berdasarkan hasil penelitian ini, menunjukkan bahwa jenis kelamin laki-laki dan perempuan sama-sama memiliki 
peran dalam tingginya angka kejadian penyakit jantung. Penelitian Rosjidi \& Isro'in, 2014 menyebutkan bahwa perempuan lebih rentan terserang penyakit kardiovakular dibandingkan lakilaki karena faktor tingginya kadar LDL dan kurangnya aktifitas fisik.

Sedangkan penelitian

Martiningsih \& Haris, 2019 menyebutkan bahwa laki-laki berada pada kelompok resiko tinggi penyakit kardiovakular disebabkan karena obesitas dan kebiasaan merokok. Berdasarkan Infodatin KemKes, 2014 bahwa perempuan lebih banyak terkena penyakit jantung dan gagal jantung sedangkan laki-laki lebih banyak terkena penyakit stroke (Infodatin KemKes, 2014; Martiningsih \& Haris, 2019; Rosjidi \& Isro'in, 2014).

b. Usia

Berdasarkan hasil penelitian ini, menunjukkan bahwa usia 66 tahun keatas rentan sekali menderita penyakit jantung dengan persentase sebesar 33,3\%. Hasil penelitian ini sejalan dengan Infodatin KemKes, 2014 bahwa penderita penyakit jantung banyak ditemukan pada kelompok umur $\geq 45$ tahun (Infodatin KemKes,

2014).

Penelitian Martiningsih \& Haris, 2019 menyebutkan bahwa semakin lanjut usia berbanding lurus dengan semakin besar reskio terjadinya penyakit kardiovaskular hal ini dipengaruhi oleh nilai kolesterol dalam darah, kurangnya aktifitas fisik, nutrisi tidak seimbang, serta konsumsi alkohol.
Kemudian dikuatkan

oleh penelitian Nugraha \&

Gusgus, 2018 yang menyebutkan

bahwa usia dan proses degeneratif

menyebabkan penurunan laju

metabolisme, penyakit degeneratif

meningkat seiring bertambahya

usia. Selain itu, pasien lanjut usia

seringkali mengalami polifarmaka

yang mengarah pada penurunan

fungsi organ sehingga menurunkan

ketersedian energi untuk

beraktifitas mengingat kedua

kondisi tersebut akan memicu

respon inflamasi kronis yang

disertai dengan kenaikan

konsentrasi mediator terutama

sitokin. Peningkatan sitokin akan

menyebabkan kelelahan pada

pasien jantung (Martiningsih \&

Haris, 2019; Nugraha \& Gusgus,

2018).

Penelitian Diatutik, 2016 menyebutkan bahwa seseorang yang berada pada kelompok usia yang lebih tua akan mengalami peningkatan kerentanan terhadap penyakit kardivaskular, akibar dari berkurangnya elastisitas pembuluh darah dalam mengalirkan darah ke seluruh tubuh (Diastutik, 2016).

c. Pendidikan Terakhir

Berdasarkan penelitian ini, menunjukkan bahwa responden lulusan SD dan SMP lebih banyak menderita penyakit jantung dibanding tingkatan pendidikan lainnya dengan persentase masingmasing $41,7 \%$. Hasil penelitian ini sejalan dengan penelitian yang dilakukan oleh Diastutik, 2016 menyebutkan bahwa tingkat pendidikan berkaitan dengan tingkat pengetahuan yang dimiliki oleh seseorang. Seseorang yang memiliki tingkat pendidikan yang lebih tinggi 
akan berdampak pada bertambahnya pengetahuan yang dimilikinya. Pengetahuan tersebut dapat digunakan sebagai upaya untuk meningkatkan derajat kesehatan dengan menerapkan perilaku hidup bersih dan sehat sebagai bentuk pencegahan terjadinya penyakit (Diastutik, 2016).

d. Pekerjaan

Berdasarkan penelitian ini, menunjukkan bahwa responden yang bekerja sebagai wiraswasta (petani dan berkebun) dan responden yang tidak bekerja lebih banyak menderita penyakit

jantung dengan persentase masingmasing sebesar $41,7 \%$.

Penelitian Diastutik, 2016 menyebutkan bahwa seseorang yang bekerja dapat dikatakan juga melakukan aktivitas fisik yang digunakan sebagai upaya melatih otot jantung sehingga jantung dapat memompa darah dengan lebih baik. Aktivitas fisik yang rutin dan cukup dilakukan juga dapat menghilangkan endapan lemak yang menumpuk di dinding pembuluh darah menuju jantung. Seseorang yang melakukan pekerjaan bahkan dapat memenuhi sekitar 30\% dari total aktivitas fisik yang dibutuhkannya. Namun jenis pekerjaan yang dilakukan juga perlu diperhatikan bagi penderita penyakit jantung maupun penderita non penyakit jantung mengingat bahwa pekerjaan yang membutuhan aktivitas fisik yang terlalu berat justru dapat membahayakan bagi kesehatan jantung itu sendiri (Diastutik, 2016).

e. Tingkat Penghasilan Berdasarkaan hasil penelitian, menunjukkan bahwa mayoritas responden dengan penyakit jantung memiliki penghasilan dibawah UMP Kaltim dengan persentase sebesar $75 \%$. Penelitian ini sejalan dengan penelitian Martiningsih \& Haris, 2019 yang menyebutkan sebanyak $42 \%$ penyakit jantung berada di negara berpenghasilan rendah dan 4\% berada di negara dengan penghasilan tinggi. Penelitian Kosim, 2015 menyebutkan bahwa tingkat penghasilan berpengaruh pada pemenuhan kebutuhan kesehatan keluarga, dengan keluarga yang sehat maka untuk aktivitas produktivitas akan berjalan dengan baik (Kosim, 2015; Martiningsih \& Haris,

2019).

f. Diagnosis Penyakit Berdasarkan hasil penelitian ini, menunjukkan bahwa hasil dari rekam medis paling banyak menunjukkan diagnosis NSTEMI pada pasien jantung di ruang intensif dengan persentase sebesar $41,7 \%$.

Penelitian Suryani, 2017 menyebutkan bahwa NSTEMI disebabkan karena ateloklerosis menyebabkan ruptur arteri koroner, menghambat aliran darah ke arteri koroner sehingga menurunkan suplai oksigen dan nutrisi ke jantung dan dapat menyebabkan infark miokard. Penelitian Itasari, 2015 menyebutkan bahwa durasi nyeri

NSTEMI lebih sedikit dibandingkan penyakit jantung lainnya seperti STEMI namun kedua penyakit ini dapat memicu serangan jantung yang mengarah pada gagal jantung. Resiko NSTEMI akan meningkat dipengaruhi gaya hidup tidak sehat, merokok, kurang aktifitas fisik, 
serta diabetes (Suryani, 2017; Itrasari, 2015).

2. Respon Kelelahan Hasil penelitian didapatkan bahwa sebanyak 58,3\% responden berada pada rentang skor 030 yang berada dalam indikator lelah. Skor terendah dari 13 pernyataan FACIT score adalah pernyataan ke 9 yaitu "saya perlu tidur disiang hari" dengan total skor adalah 11 (21\%). Pada pernyataan ini sebagian responden mengatakan bahwa mereka perlu tidur disiang hari, dan sebagian reponden mengatakan bahwa harus tidur siang. Hal ini sejalan dengan penelitian Dewi, 2017 yang mengatakan bahwa pasien jantung biasanya disertai gangguan tidur yang dapat terjadi pada siang hari sehingga tidur siang berkepanjangan, atau pada malam hari yaitu sering terbangun. Kemudian didukung oleh penelitian Lainsamputty \& Hsing, 2018 yang menyebutkan bahwa pasien dengan kelelahan mungkin membutuhkan lebih banyak tidur siang dan lebih lama tidur malam untuk memulihkan energi, ataupun pada kondisi tertentu kelelahan yang menghabiskan energi dan tegana fisik menyebabkan pasien untuk mnghabiskan lebih banyak waktu ditempat tidur. (Dewi, 2017; Lainsamputty \& Hsing, 2018).

Pada kondisi ini, salah satu intervensi yang dapat dilakukan agar kebutuhan tidur pasien terpenuhi dan mendapatkan kualitas tidur yang baik untuk konservasi energi adalah dengan terapi posisi lateral kanan. Penelitian yang dilakukan oleh Yesni, 2019 menyebutkan bahwa pemberian posisi lateral kanan selama 30 menit menjelang tidur memberi kenyamanan secara fisik pada jantung. Gravitasi dapat meningkatkan beban kerja jantung ketika berbaring kearah kiri sedangkan jika berbaring ke arah kanan akan meningkatkan aktivitas vagal (saraf parasimpatis), pada posisi istirahat lateral kanan akan mencegah obstruksi saluran nafas daerah faring akibat pendorongan lidah dan palatum kebelakang yang dapat menyebabkan oklusi nasofaring dan orofaring pada saat pasien tidur, sehingga pasien akan merasa nyaman ketika tidur di posisi ini (Yesni, 2019).

Kemudian, didukung oleh penelitian Muti, 2020 menyebutkan bahwa posisi lateral kanan dapat menyebabkan beban kerja jantung yang lebih kecil pada fungsi pernapasan sehingga posisi lateral kanan sangat berpengaruh terhadap peningkatan saturasi oksigen $(\mathrm{SaO} 2)$ dan respirasi. Pasien dengan penyakit kardiopulmonal yang mengalami keluhan sesak, tidak dapat tidur dalam posisi berbaring melainkan harus dalam posisi duduk atau setengah duduk. Berbagai posisi yang dapat digunakan untuk mengatasi ketidaknyamanan akibat sesak diantaranya adalah posisi fowler, semi fowler, dan posisi ortopnea. (Muti, 2020).

Penelitian ini menunjukkan bahwa sebagian besar responden mengatakan merasa lelah dan lemah di seluruh tubuh, sering kali merasa lesu atau tidak berdaya, hanya ingin duduk atau berbaring, mengalami kesulitan memulai sesuatu karena merasa lelah, namun beberapa responden merasa masih mempunyai energi dan masih mampu melakukan aktifitas yang biasa dilakukan seperti makan, mayoritas responden mengatakan perlu tidur disiang hari, sebagian besar responden tidak merasa lelah pada saat makan namun dengan porsi makan lebih sedikit, sering kali responden memerlukan bantuan orang lain untuk melakukan aktifitas seharihari, mayoritas responden 
tidak merasa frustasi karena lelah yang dirasakan tetapi hanya kepikiran mengenai keinginan untuk cepat sembuh dan pulang kerumah, dan sering kali responden harus membatasi aktifitas yang biasa dilakukan.

Penelitian ini sejalan dengan penelitian yang dilakukan oleh Putri dkk, 2018 menyebutkan bahwa kelelahan pada pasien dengan penyakit jantung menyebabkan responden tidak mampu mengerjakan banyak pekerjaan, serta banyak responden yang hanya melakukan aktifitas ringan dan lebih sering duduk. Hal ini didukung oleh penelitian Utami, 2019 yang menyebutkan bahwa pasien jantung yang mengalami kelelahan cenderung pesimis akan olahraga dan menghindari aktivitas fisik sehingga kurang berpartisipasi dalam aktivitas fisik (Putri dkk, 2018; Utami, 2019).

Penelitian yang dilakukan oleh Wahyudi dkk, 2018 menyebutkan bahwa pasien jantung mengalami penurunan kontraktilitas disebabkan karena suplai oksigen menurun ke jantung menurun serta adanya penyumbatan arteri akibat aterosklerosis maka aliran darah ke arteri koroner berkurang dan menyebabkan penderita jantung mengeluh cepat lelah dan berdampak pada activity daily living serta sebagian besar responden menganggap kelelahan adalah bagian dari proses penuaan. Hal ini didukung oleh penelitian yang dilakukan oleh Nugraha dkk, 2018 bahwa kelelahan yang dialami responden dengan penyakit jantung adalah akibat dari penurunan fungsi jantung karena semakin tingginya umur seseorang (Nugraha dkk, 2018; Wahyudi dkk, 2018).
Pada kondisi ini, salah satu intervensi yang dapat diberikan yaitu terapi jalan kaki. Selain untuk membantu memperlancar peredaran darah, terapi ini juga termasuk aktiftas ringan dan mudah dilakukan terutama bagi usia lanjut. Penelitian Puspitasari dkk, 2017 mengatakan bahwa aktifitas jalan pagi memiliki pengaruh terhadap perubahan tekanan darah pada lansia. Manfaat besar dengan rajin olahraga dipagi hari yaitu sirkulasi darah yang baik, kekuatan otot dan stamina, mengontrol gula darah, peningkatan kualitas kulit, kualitas tidur yang baik, perbaikan metabolisme tubuh, penyerapan vitamin $\mathrm{D}$ dan kesehatan mental yang baik. Olahraga yang sesuai dan efektif dapat meningkatkan angka harapan hidup sehingga derajat kesehatan dapat meningkat. Penelitian ini didukung oleh penelitian Aritonang, 2018 bahwa latihan Home Heart Walk atau jalan enam menit dapat meningkatkan curah jantung dan mengurangi sesak nafas dan kelelahan. Peningkatan oksigen dan energi dapat mengurangi kelelahan yang dirasakan oleh pasien jantung. Latihan Home Heart Walk paling efektif mulai pada minggu ketiga dan keempat untuk menurunkan derajat kelelahan. Di dalam jurnal Home Heart Walk dilaksanakan selama 9 bulan, tetapi menurut Aritonang, 2018 Home Heart Walk boleh dilakukan minimal enam minggu supaya mendapatkan hasil yang cepat dan bermanfaat buat responden dalam menurunkan derajat kelelahan (Aritonang, 2018; Puspitasari dkk, 2017).

\section{KESIMPULAN}

Berdasarkan hasil penelitian, didapatkan jenis kelamin setara antara laki-laki sebesar $50 \%$ dan perempuan sebesar $50 \%$, usia terbanyak yaitu masa manula (66 tahun keatas) sebesar 33,3\%, pendidikan terakhir terbanyak adalah SD dan SMP masing-masing sebesar $41,7 \%$, pekerjaan 
terbanyak adalah wiraswasta dan tidak bekerja masing-masing sebesar $41,7 \%$, tingkat penghasilan terbanyak adalah dibawah UMP Kaltim sebesar 75\%, diagnosis penyakit terbanyak adalah NSTEMI sebesar 41,7\%. Kemudian hasil pengukuran FACIT score didapatkan bahwa sebanyak $58,3 \%$ responden mengalami kelelahan.

\section{REFERENSI}

Amin, M., A. (2017).

Klasifikasi Kelompok Umur Manusia

Berdasarkan Analisis Dimensi Fraktal Box Counting Dari Citra Wajah Dengan Deteksi Tepi Canny. MATHunesa Jurnal Ilmiah Matematika, 2(6). 33-42. ISSN 2301-9115.

Amiyati. (2018). Manajemen Askep Pasien Gagal Ginjal Kronik Terminal Dengan Faktor Resio Riwayat Hipertensi, Study Penerapan Evidance Based

Nursing Efek Aromaterapi Dengan Minyak Essensial Lavender Pada Tingkat Kelelahan Pasien Yang Menjalani Hemodialisa, Inovasi Efektifitas Pemberian Gel Lidah Buaya Pada Pasien Gagal Ginjal Kronik Dengan Masalah Pruritus Di Ruang Hemodialisa RSUD Abdul Wahab Syahranie

Samarinda. Karya Ilmiah Akhir Ners. STIKES Wiyata Husada

Samarinda. Tidak dipublikasikan.

Anastastya, N., dkk. (2016). Perancangan Media Informasi Tentang Aritmia Jantung Bagi Anak Remaja Usia 15-20 Tahun. Jurnal DKV Adiwarna, 1(8). 1-9.

Andani, G., J. (2016). Analisis Perlakuan Akuntansi Atas Pendapatan Dan Beban Serta Pelaporan Keuangan Pada Pt Anugrah Artha Abadi Nusa
Palembang. Palembang: Politeknik Negeri Sriwijaya

[Thesis].

Ardianta, D. (2017). Upaya Peningkatan Intoleransi Aktivitas Pada Pasien Congestive Heart Failure. Surakarta: Univesitas

Muhammadiyah Surakarta

[Naskah Publikasi].

Aritonang, Y., A. (2018). Efektifitas Home Heart Walk Terhadap Derajat Kelelahan Pada Penderita Gagal Jantung Di Jakarta. Prosiding AKPER Yayasan UKI. 10-19. ISBN: 978-979-9146-71-2.

Aspiani, R. Y. (2017). Buku Ajar Asuhan

Keperawatan Klien Gangguan Kardiovaskular Aplikasi NIC \& NOC. Jakarta: EGC.

Asyrofi, A., dkk. (2016). Residensi Keperawatan Dan Penerapan Model Konservasi Myra Estrin Levine Pada Pasien Gangguan Sistem Kardiovaskular. Jurnal hasil Riset. $1-14$.

Black, J. M \& Hawks, J., H. (2014). Keperawatan Medikal Bedah. Manajemen Klinis Untuk Hasil yang Diharapkan. Edisi 8. Buku 3. Singapura: Elsvier.

Borges, J., A., dkk. (2018). Fatigue: A

Complex Symptom and Its Impact on Cancer and Heart Failure.

International Journal of

Cardiovascular Sciences, 31(4).

433-442. doi: $10.5935 / 23594802.20180027$.

Dahlan, S. (2018). Langkah-langkah Membuat Proposal Penelitian Bidang Kedokteran dan Kesehatan. Seri 3. Edisi 2. Jakarta: Sagung Seto.

Dewi, I., P. (2017). Kualitas Tidur Pasien 
Gagal Jantung Dan Penanganannya. Jurnal Keperawatan Komprehensif, 3(1). 18-24. DOI: https://doi.org/10.33755/jkk.v3i1. 80

Diastutik, D. (2016). Proporsi Karakteristik Penyakit Jantung Koroner Pada Perokok Aktif Berdasarkan Karakteristik Merokok. Jurnal Berkala

Epidemiologi, 4(3). 326-337. doi: 10.20473/jbe.v4i3.

Firmansyah, E. (2013). Pengelolaan Hutan Berbasis Masyarakat (PHBM) DI Kawasan Hutan Lindung Desa Mandalamekar Kecamatan Jatiwaras Kabupaten Tasikmalaya. Antologi Pendidikan Geografi, 1(1). 1-9.

Hanawati, F. (2019). Upaya Peningkatan Toleransi Aktivitas Pada Pasien Infark Miokard Akut Melalui Manajemen Energi Di Ruang Intensive. Surakarta: PKU Muhammadiyah Surakarta [Jurnal Publikasi].

Hartoko, Y. (2018). Pengaruh Pendidikan, Pelatihan, Jenis Kelamin, Umur, Status

Perkawinan, Dan Derah Tempat Tinggal Terhadap Lama Mencari Kerja Tenaga Kerja Terdidik Di Indonesia. Yogyakarta: Universitas Negeri Yogyakarta [Skripsi].

Hirshkowitz, M. (2013). Fatigue, Sleepiness, and Safety. Definitions, Assessment, Methodology. Sleep Medicin Clinic, 8(2). 183-189. https://doi.org/10.1016/j.jsmc.201 3.04.001.

Itrasari, A. (2015). Hubungan Jenis Sindrom Koroner Akut dengan Kualitas Hidup Aspek Fisik Pasien Pasca Serangan Jantung yang Dirawat di RS PKU
Muhammadiyah Yogyakarta. Yogyakarta: STIKES 'Aisyiyah Yogyakarta [Naskah Publikasi]. Jaenudin, E. (2018). Akna Kerja Bagi

Guru Khidmah Di Pondok Pesantren Al Luqmaniyah Yogyakarta. Yogyakarta:

Universitas Mercu Buana Yogyakarta [Skripsi].

Karmila, V., D. (2018). Gambaran Dukungan Suami Terhadap Istri

Yang Menggunakan Alat Kontrasepsi IUD (Sebuah Studi Deskriptif) Di Puskesmas Loa Ipuh Tenggarong. Samarinda: Sekolah Tinggi Ilmu Kesehatan Wiyata Husada Samarinda

[Skripsi].

Kasron. (2012). Buku Ajar: Gangguan Sistem Kardiovaskuler. Yogyakarta: Nuhamedika.

Kementerian Kesehatan RI. (2014). Situasi Kesehatan Jantung. Info Datin Pusat Data dan Informasi Kementerian Kesehatan RI. https://www.kemkes.go.id/article/ view/15021800003/situasikesehata n-jantung.html.

Kosim, N. (2015). Faktor Yang Mempengaruhi Kualitas Hidup Penduduk Di Desa Sentul Kecamatan Sumbersuko Kabupaten Lumajang. Jember: Universitas Jember [Skripsi].

Lainsamputty, F., \& Hsing, M., C. (2018). The Correlation Between Fatigue And Sleep Quality Among Patients With Heart Failure. NurseLine Journal, 3(2). 100-114.

DOI: https://doi.org/10.19184/nlj.v3i2.8 580.

Malla, K., T. (2019). Pengaruh Latihan Fisik (In Patient) Terhadap Activity of Daily Living Pada Pasien Dengan Penyakit Jantung Sindrom 
Koroner Akut di RSUD Prof. Dr. W. Z. Johannes Kupang. CHM-K Applied Scientific

Journal, 2(3). 87-92.

Martiningsih, \& Haris, A. (2019). Risiko

Penyakit Kardiovaskuler Pada

Peserta Program

Pengelolaan Penyakit Kronis

(PROLANIS) Di

Puskesmas Kota Bima: Korelasinya

Dengan Ankle Brachial Index Dan

Obesitas. Jurnal Keperawatan Indonesia,

22(3). 200-208. DOI:

10.7454/jki.v22i3.880.

Manurung, W. P., \& Wibowo, A. (2016).

Pengaruh Konsumsi Semangka

(Citrullus vulgaris) untuk

Menurunkan Tekanan Darah pada

Penderita Hipertensi. Jurnal

Majority, 5(5). 102-107.

Matura, L., A., dkk. (2018). A Systematic

Review of Biological Mechanisms

of Fatigue in Chronic Illness.

Biological research for nursing,

20(4). 1-12. DOI:

$10.1177 / 1099800418764326$.

Morton, P., G., dkk. (2017). Keperawatan

Kritis Pendekatan Asuhan Holistik

Edisi Revisi. Volume 1. Edisi 8. Jakarta: EGC.

Muti, R., T. (2020). Pengaruh Posisi Semi Fowler Dengan Kombinasi Lateral Kanan Terhadap Perubahan Haemodinamik Pada Pasien Gagal Jantung Di Ruang ICCU Rumah Sakit Umum Daerah Margono Soekarjo Purwokerto. Viva Medika: Jurnal Kesehatan, Kebidanan, dan Keperawatan,

13(2). 124-140.

Nugraha, B. A., dkk. (2017). Pengaruh Pijat Punggung terhadap Skor Kelelahan Pasien Gagal Jantung. Jurnal Keperawatan Padjadjaran, 5(1). 65-72.
Nugraha, B., A., \& Gusgus, G., R. (2018).

Kelelahan Pada Pasien Dengan Penyakit Kronis.

Prosiding Seminar Nasional dan Diseminasi Penelitian Kesehatan, 1(1). 7-13. ISBN:978-602-7263635.

Nugraha, B., A., dkk. (2018). Gambaran Kelelahan Pada Pasien Gagal Jantung. Jurnal Medika Cendikia, 5(1). 16-21.

Nursalam. (2011). Konsep dan Penerapan Metodologi Penelitian Ilmu Keperawatan. Pedoman Skripsi, Tesis, dan Instrumen Penelitian Keperawatan. Edisi 2. Jakarta: Salemba Medika.

Permana, I., S., \& Yusuf, S. (2018). Sistem Pakar Untuk Mendiagnosa Penyakit Kulit Dengan Metode Forward Chaining. JUMANTAKA: Jurnal Manajemen dan Teknik Informatika, 1(1). 361-370. PISSN: 2613-9138-EISSN: 26139146.

Puspitasari, D., I., dkk. (2017). Pengaruh Jalan Pagi Terhadap Perubahan Tekanan Darah Pada Lanjut Usia Dengan Hipertensi Di Desa Kalianget Timur Kecamatan Kalianget Kabupaten Sumenep. Jurnal Ners Lentera, 5(2). 169177. ISSN: 2338-624X.

Putri, R. (2018). Faktor Resiko Hipertensi Ditinjau Dari Stres Kerja Dan Kelelahan Pada Anggota Polisi Daerah Riau. Psychopolytan: Jurnal Psikologi, 2(1). 36-48.

Putri, D., N., dkk. (2018). Fatigue dan Aktivitas Fisik pada Pasien Pasca Infark Miokard. NERS: Jurnal Keperawatan, 14(2). 44-51.

https://doi.org/10.25077/njk.14.2. 4552.2018. Rosjidi, C., H., \& Isro'in, L. (2014). 
Perempuan Lebih Rentan Terserang Penyakit Kardiovakular. Jurnal Florence, 7(1). 1-10.

Ryandini, F., R., dkk. (2017). Penerapan Teori Self Care Untuk Mengatasi Intoleransi Aktivitas Pada Pasien Dengan Gangguan Sistim Kardiovaskular. Jurnal Ilmu Keperawatan dan Kebidanan, 9(1). 1-8.

Safitri, T., A., \& Retnaningsih, D. (2018). Modul Statistik Deskripsi. Yogyakarta: Universitas 'Aisyiyah Yogyakarta. ISBN: 978-60261757-8-6.

Sari, E., T. (2019). Stres Dalam Hubungannya Dengan Fatigue Pada Pasien yang Menjalani Terapi Hemodialisa Di Unit Hemodialisa RS Dr. Haryoto Lumajang. Jember: Universitas Jember [Skripsi].

Sastroasmoro, S. \& Ismael, S. (2014). Dasar-dasar Metodologi Penelitian Klinis. Edisi 5. Jakarta: Sagung Seto.

Sekarsari, R., \& Ade, I., S. (2016). Gambaran Aktivitas Sehari-Hari Pada Pasien Gagal Jantung Kelas II Dan III Di Poli Jantung RSU Kabupaten Tangerang. Jurnal

JKFT, 1(2). 1-7. http://dx.doi.org/10.31000/jkft.v2i 2.7 .

Sihombing, J., P., dkk. (2016). Validasi Kuesioner Skala Kelelahan FACIT pada Pasien Penyakit Ginjal Kronis yang Menjalani Hemodialisis Rutin. Jurnal Farmasi Klinik Indonesia, 5(4).

231-237.

DOI:10.15416/ijcp.2016.5.4.231

Sugiyono. (2011). Metode Penelitian Kuantitatif Kualitatif Dan R\&D. Bandung: Alfabeta.
Sugiyono. (2016). Metode Penelitian Kuantitatif, Kualitatif, dan R\&D. Bandung: Alfabet Penerbit.

Suryani, A. (2017). Analisa Praktik Klinik Keperawatan pada Klien dengan Acute Coronary Syndrome (ACS NSTEMI) dengan Terapi Inovasi Kompres Hangat terhadap Nyeri di Ruang Intensive Care Unit (ICCU) RSUD Abdul Wahab Sjahranie Samarinda Tahun 2017. Karya Ilmiah Akhir Ners. STIKES Muhammadiyah Samarinda.

Suryani, I. (2018). Analisa Praktik Klinik

Keperawatan. Penerapan

Progressive Muscle Relaxation Dalam Manajemen Energi Pada Pasien Acute Coronary Syndrome (NSTEMI) Yang Mengalami

Kelelahan. Karya Ilmiah Akhir Ners. STIKES Wiyata Husada Samarinda. Tidak dipublikasikan.

Suswandari. (2016). Kode Etik Penelitian dan Karya Ilmiah UHAMKA.

Jakarta: Universitas

Muhammadiyah Prof.Dr.Hamka.

Tenant, K., F. (2019). Assessment of Fatigue in Older Adults: The FACIT Fatigue Scale (Version 4). Diakses pada tanggal 13 Februari 2020. http://www.facit.org/FACITOrg/ Questionnaires.

Utami, M., P., dkk (2019). Beda Luaran Fungsi Sensorimotor Pasien Dengan Dan Tanpa Fatigue Pascastroke Iskemik. Neurona (Majalah Kedokteran Neuro Sains Perhimpunan Dokter Spesialis Saraf Indonesia), 36(2). 113-119.

Wahyudi, R., dkk. (2018). Efektivitas

Breathing Exercise Terhadap Penilaian Tingkat Kelelahan Pada Pasien Penyakit Jantung Koroner. 


\section{NURSING UPDATE:}

Jurnal Ilmiah Ilmu Keperawatan, 1(2). 70-77.

Widiastuti, Ani. (2012). Analisis Laporan

Praktek Residensi Spesialis

Keperawatan Medikal Bedah

Dengan Penerapan Teori

Konservasi Levine Pada Kasus

Kardiovaskuler Di Rumah Sakit

Jantung Harapan Kita Jakarta.

Jakarta: Universitas Indonesia

[Karya Ilmiah Akhir].

Yesni, M. (2019). Pengaruh Terapi Posisi

Lateral Kanan Terhadap Kualitas

Tidur Pasien Gagal Jantung Di Rsup

M Djamil Padang. Jurnal

Akademika Baiturrahim, 8(1).

117-125.

DOI:

http://dx.doi.org/10.36565/jab.v8i

1.109 .

Zulaihah. (2019). Gambaran Fatigue Pada Pasien Gagal Jantung Di Poli

Jantung RS Tipe C Jember.

Jember: Universitas Jember

[Skripsi]. 